\title{
Spirit Possession in a Present-Day Russian Village
}

\author{
Olga Khristoforova \\ Centre for Typological and Semiotic Folklore Studies \\ Russian State University for the Humanities \\ Moscow, Russia.
}

\section{Abstract}

The article is based on the data collected in the period from 1999 to 2005 during the author's field work among the Old-Believers of the Urals and Udmurtia (Verkhokam'e historical region). The author examines beliefs in spirit possession which have existed in this region since at least the beginning of XVIII century. Local synonymous terms for spirit possession are ikota and poshibka. In the present-day Verkhokam'e one can find not only a large corpus of folkloric memorates about ikota/poshibka, but also actual persons who consider themselves to be possessed by or to have ikota. Other persons in their social environment share this diagnosis.

The author analyzes a large number of folkloric memorates about ikota as well as interviews with possessed persons. She reviews the semantics, pragmatics, and social functions of ideas about spirit possession in the Verkhokam'e.

Beliefs in the possession of a human being by evil spirits have been attested in Russia since at least the eleventh century (Pigin 1998; Lavrov 2000; Mel'nikova 2006). This phenomenon, also called klikushestvo, klikota, or ikota, was widespread and attracted public attention in the $19^{\text {th }}$ century when it appeared in the writings of priests, journalists, historians, doctors, ethnographers, and folklorists (Shteinberg 1870; Drzhevetskii 1872; Efimenko 1864, 1877; Krainskii 1900; Maksimov 1987[1859]; Popov 1903; Pryzhov 1996[1865]; Beliaev 1905; Osipov 1905; Novombergskii 1906; Golikova 1995). The rich data gathered at that time permit detailed research on this topic (Vinogradova 2000; Worobec 2001). Researchers have not, however, investigated contemporary beliefs and practices related to the possession of a human by a malevolent being.(1) This is the case because the topic was taboo throughout most of the $20^{\text {th }}$ century and because folkloric texts about the phenomenon disappeared or their distribution was substantially reduced.(2) Still, there are places like the Russian North, the Urals, and Siberia where the 
phenomenon of possession has survived until the present and tradition bearers use a stable set of semantic markers for its description. One of the regions where the phenomenon persists is the Verkhokam'e [literally - the Upper Kama region, transl.] where the Old Believers-bespopovtsy of the Pomor assent (soglasie) live in a compact community.

In this article, I will review the semantics, pragmatics, and social functions of ideas about spirit possession in the Verkhokam'e. The fieldwork data were gathered during 1999-2003, when I participated in a composite expedition organized by the Archeography Laboratory of M. V. Lomonosov State University in Moscow, as well as during 20042005, when I conducted fieldwork on my own.

\section{Historical references}

The Verkhokam'e is a historical region near the source of the Kama river; it lies to the southwest of the Perm' oblast' and to the northeast of the Udmurt territory. Its area is 60 square kilometers and comprises the Vereshchagin and Sivin provinces of the Perm' oblast' as well as the Kezs province of the Udmurt territory. The toponym "Verkhokam'e" is a generic name which local people applied to this land in the first half of the $18^{\text {th }}$ century. Russian settlers appeared in this region in the $16^{\text {th }}$ century and pushed out the aboriginal inhabitants, the Udmurts and Komi-Permiaks. Due to the church schism at the end of the $17^{\text {th }}$ century, significant numbers of people from the Central and Northern provinces of Russia migrated to the region. In the second third of the $18^{\text {th }}$ century, the Old Believers from the Vygovsk kinoviia (a commune-monastery) became dominant in the region, thus the Verkhokam'e became a stronghold of the Pomor division of bespopovstvo (the division of Old Believers who do not acknowledge a priesthood - trans.). Both geographical and cultural isolation and the people's longing for "the ancient ways of life" contributed to the persistence of archaic features in language and culture. A "secondary archaization" came in the second half of the $19^{\text {th }}$ century when local Old Believers split into two confessions, the Deminskoe and Maksimovskoe, because of differences of opinion among church elders and mutual accusations of lack of piety. Missionary activities in the Verkhokam'e by the Orthodox Church began in the first half of the $19^{\text {th }}$ century. The belokrinitskaia (popovskaia [meaning the division which does have a clergy - trans.]) church of the Old Believers began its missionary work in the middle of century. Newcomers increased in number at the end of the $19^{\text {th }}$ and at the 
beginning of the $20^{\text {th }}$ centuries when the Trans-Siberian Railway was built through the region. Today, the Verkhokam'e is both a multiethnic and multiconfessional region: Russians and Udmurts, Orthodox and Old Believers of various confessions including popovtsy, belokrinitskie bespopovtsy, the Pomors, chasovennye, and stranniki live there side by side.(3)

Ideas about possession, or poshibka, called ikota in the vernacular, are preserved mainly by the aboriginal population, i.e., the Pomor Old Believers. We refer to this group as aboriginals because the very first aboriginal population of the Komi-Permiaks was either assimilated or pushed out of the Verkhokam'e about a century ago. Ideas about possession do not exist in isolation but constitute part of a complex system, which includes elements of material culture (exterior construction and interior design of houses, clothing, and cuisine); norms of social interaction (a custom of "assistance [pomoch']"; codes of everyday and festive behavior); rituals and beliefs related to various beings like sorcerers, the domovoi (a house spirit), or leshii (a forest spirit); a custom of giving a river or bathhouse as a "gift," and other elements (Nikitina 1993; Smilianskaia 1998; Chagin 1998). This system bears some very archaic traits due to the conservatism of the Old Believers and their intentional isolation from the outer, "Antichrist," world.

\section{Terminology}

In the Verkhokam'e, there are three synonymous words used to define possession. These same words are used for the being that causes possession. These are bol'/bolest', poshibka, and ikota. "Bol'/bolest"' is a generic term as it basically means 'illness', and it is used to define other illnesses, especially serious ones like typhus. The two other words require further explanation.

The words ikota and poshibka are derived from their corresponding verbs. The verb ikat', as used in the Verkhokam'e and in the Russian North in general, refers to the actions of a sick person. People consider fits of involuntary hiccupping to be a symptom of possession. The dialectal verb ikat' also means the same as klikat', namely 'to shriek, exclaim" (Merkulova 1988: 311). The second verb, poshibat', refers to actions by a sorcerer that are used to cast a spell:

Poshibat', poshibit' (somebody) - to beat down, hit, overpower, strike (Dal' 1882 3: 373). 
Poshibat' - to mar, disfigure, mutilate (Arkhangel'sk region), to knock down, destroy, overpower (Olonetsk, Smolensk, Moscow, and Vladimir regions and ff.); poshibennyi - 1) dejected, injured; 2) emaciated, puny, weak (Iaroslavl' region); poshibalka - an object that can be tossed at someone or something (regions of Pskov, Tver', Tambov) (Filin 1977 31: 31-32).

The word poshibka has three homonymous meanings: 1) a mistake (Onega region), 2a) a fight, skirmish, 2b) a habit (povadka) (Olonetsk region); 3a) an infectious disease of domestic animals (regions of Perm' and Tobol'sk), 3b) an illness sent or a spell cast by a sorcerer (Perm' region) (Filin 1977 31: 32). The last meaning, the most recent in origin and probably a euphemistic one, is attested in the Perm' region only. It is not mentioned in dialect dictionaries of the Russian language applying to any other region.

The word ikota has two etymologically related meanings. One is hiccups and this is a meaning which is widespread. The other refers to a nervous illness and this meaning is found in dialects only. Both meanings are given by Vladimir Dal', though he gives a more detailed description of the latter:

Ikota, ikotka - is a disease or a state of a person who hiccups. In the North, especially in Perm', it is a local, mostly female illness, which is attributed to a spell (porcha, napusk). An afflicted female is then called klikusha, ikotnaia, or ikotnitsa. The disease comes in fits like epileptic ones, accompanied with writhing - especially if [a sick person is] irritated. An ikotnik is a person afflicted by this disease. This word can also refer to a sorcerer who is said to pin or inflict ikota on women (Dal' 1882 2: 40).

\section{Contemporary dialectical dictionaries give a more detailed definition:}

Ikota - A nervous histrionic disease that occurs mainly in females; it manifests itself in the convulsive fits during which sick persons yell and shriek: klikushestvo. The idiom: ikota speaks (ikota govorit) applies to a fit of a nervous histrionic disease; e.g. ikoty-chatter-boxes (ikotygovorukhi) (Arkhangel'sk region). To speak with ikota (ikotoi govorit') means to suffer from a fit of a nervous histrionic disease. Ikota-chatterbox (ikota-govorukha) refers to a less intense nervous histrionic disease which manifests itself in the sick person as fits of speaking rather than shrieking; such a person is nevertheless unable to respond to questions (Arkhangel'sk region). Mute ikota (ikota nemaia) is a histrionic nervous disease characterized by loss of ability to speak, the afflicted person 
producing only inarticulate, abrupt shrieks (Arkhangel'sk region). Deadly ikota (ikota smertnaia) is a histrionic nervous disease which leads to the afflicted person dying during a fit (Arkhangel'sk region). To inflict ikota (napustit', nasadit', posadit' ikotu) means to cause a nervous, histrionic disease by means of black magic or the evil eye. The second definition of ikota is that it is an evil spirit that, according to folk belief, gets inside a human and causes a nervous disease, namely klikushestvo. Another definition labels it as a person suffering from klikushestvo, a person possessed by an evil spirit. The final definition states that ikota means being racked by whims of a morbid nature (Filin 1977 12: 181).

According to V. A. Merkulova, the word ikota in the meaning of an illness or a histrionic fit appeared in the XV-XVII centuries in the Russian North and was based on a specific local meaning of the verb ikat'. In this context ikat' was synonymous with the verbs krichat', svat' and meant to scream or to call. It was formed on the same semantic model which produced the word klikota (meaning histrionic fit) from klikat' (1988: 311). According to other scholars, the name ikota derived from the exhausting, nervous hiccupping that typically accompanied a fit (Klementovskii 1860: 213, Maksimov 1987 2: 111, Efimenko 1877: 200; Martynov 1905: 220).

The word poshibka in the euphemistic meaning of magical spoiling is semantically equivalent to the word ikota in dialectic meanings 1 and 2 above (Filin 1977 12:181). In the text I will use the term poshibka for two reasons: first, this word is specific to the Verkhokam'e region where the materials used for this article were collected; second, this term is less fluid and refers primarily to an evil spirit that gets inside a human and causes a nervous disease. This supernatural being is the primary concern of this article.

\section{Anthropological interpretations of ikota/poshibka.}

In contemporary anthropology, the physiological basis of ikota is generally considered to be the startle reflex, a mild form of epilepsy which is a physiological reaction to extreme fright. The reflex manifests itself in outbursts of screaming, convulsions, grimacing, heightened suggestibility and echopraxis and echolalia (the repetition or mimicking of the gestures or words of others). Sometimes corpopraxis and corpolalia (the use of indecent gestures and words) also occur. In addition to ikota, the startle reflex is known under the following names: 
latah in Malaysia, miriachenie in Siberia (from the verb miriachit'), pibloktok among the Eskimo, and Arctic hysteria (Simons and Hughes 1985: 484, 486). The terms klikushestvo and poshibka are not used for this phenomenon. The condition most like North Russian ikota is Malaysian latah. This is a disease attested in Malaysia and Indonesia which affects women, primarily elderly ones who have experienced significant stress. The symptoms of latah are increased excitability, involuntary gestures and crude and obscene exclamations in response to irritants such as a loud sound or a sudden movement. Women suffering from latah are an object of interest in the community. Their condition is a subject of discussion and youngsters entertain themselves by engaging in behaviours which prompt their fits. The difference between the two conditions is a significant one, however. Latah, unlike ikota, is not seen as something which is acquired. Thus it is not believed to be caused by magic and cannot be exorcized. The illness does not grant the ability to foretell the future or locate lost objects. Furthermore, acquired as opposed to spontaneous illnesses in Southeast Asia and other regions have physiological symptoms that are markedly different from ikota. (Belo 1960; Prince 1968; Crapanzano 1977; Kleinman 1980; Danforth 1989; Goodman 1996; Littlewood 2000; Lewis 2003).

Efforts to liken ikota to Turette's syndrome with its tick-like hyperkinesis which can include impulsive echolalia and coprolalia, have been unsuccessful. Turette's syndrome, unlike ikota, is considered to be an organic, pathological condition of the brain, is found primarily in males, and shows no tendencies to spread in an epidemic-like fashion (Blaker and Crook, 1995: 205) Ikota is sometimes attributed to ergotism, poisoning by mold spores which grow on rye and are common in rainy, cold years (Matossian 1989). This explanation is based on concepts popular in the 1970s and 80s which attributed mass epidemics and consequent witch hunts in Europe and America to natural causes such as syphilis, calcium deficiency, plant poisoning, all of which could have caused seizures and hallucinations. These might, in turn have led to accusations or confessions of witchcraft (Andreski 1989; Mappen 1980; Harner 1973; Camporesi 1989). Worobec, who, in a recent monograph on klikushestvo, examines ergotism and calcium deficiency as possible causes, rejects these explanations in favor of a socio-cultural interpretation of this phenomenon (Worobec 2001: 192, 195-199)(4). 


\section{The Semantics of the poshibka concept}

During six years of fieldwork, I gathered a large corpus of folkloric texts about poshibka. The texts are mostly bylichki, meaning memorates or stories of personal experience and direct answers to the interviewer's questions about cultural facts and beliefs. Is it doubtful that the last category of expression would exist without prompting by the researcher. Fabulates, or stories about the experiences of others seldom occur, and are probably adaptations of written literature, such as published fairytales retold in legend form.

The main themes of the memorates include the creation or dispatching of a poshibka by a sorcerer; its implantation into a human; its behavior inside a human, and its expulsion from its human host. Although all respondents agreed that a poshibka is nothing other than a demon (devil, unclean spirit, "hellish force"), its appearance, name, and behavior depended on the plot of the narrative.

\section{Origin and appearance}

\subsection{The origin of a poshibka}

A sorcerer/witch creates a poshibka by growing it in a cellar or in a birch-bark vessel (tuesok). In this case, the supernatural being appears as a worm, spider, or an amphibian like a frog. The witch or sorcerer can create a poshibka by whispering over straw or matches. A poshibka in this case would have the appearance of a straw or match. Another means of creating a poshibka is by cutting a human figure out of paper. A poshibki then looks like drawn human figures or "dolls."

\subsubsection{Broadcasting or spreading the poshibka}

A sorcerer/witch spreads a poshibka by sending it on the wind. In this case a poshibka appears as a straw or an insect like a fly, a mosquito, or a midge. It can also look like a drawn human figure of unspecified appearance. The witch or sorcerer can place the poshibka under a tree or next to a well or a river. It can be put by the gates or fence of a farmstead. In neither case is the appearance of a poshibka specified. Finally, a poshibka, also of unspecified appearance, can be transmitted by bodily contact.

Examples: 
Фотинька, Пашкина мы ее звали всё. Фотинька Пашкина... И-от, стали хоронить, у её в подполье нашли туесок, ну бурачок, туесок, берестяный такой, там нашли у её, туесок стоит, это, говорит, открыли - там полно, одни мизгири Это всё там у ёй гадость всякая. Вот, этот мизгирёк, значит, он, на кого она придумала посадить, и всё

[We called her Pashkina, Fotin'ka.Fotin'ka Pashkina... And when we were burying her, we found a birch-bark vessel (tuesok) in her cellar; well, a vessel made of a birch bark stood there, and, they say, they opened it and it was full of spiders (mizgiri). And she had all sorts of muck there. So this spider - she was planning on planting it on someone, and that's it.] (E.E.N., female, born in 1924; Siv; 2002, recorded by M. Akhmetova and A. Koz'min).

Так один старичок так говорил: я, говорит, нарисую куклы, маленькие куклочки. Они, говорит, у меня, рисунки, прямо с бумаги это, выходят, играют-играют на этой бумаге, а потом, значит, я их посылаю - дверь открою, посылаю, и они у меня улетают, и летят, куда он пошлет... Или может даже взять из соломинки куклу, послать, и она действует, эта соломинка

[Here's what one old man said: I draw dolls, little dolls. My drawings come out of the paper and play on the paper; and then I send them out: I open the door, send them out, and they fly away. They fly where he would send them... Or he can even take a piece of straw and send it out, and this straw has its effect] [E.S.T., male, born in 1953; Siv.; 2005, recorded by M. Guseva, N. Sarafanova, and O. Khristoforova).

Вот я пример приведу. Был у нас коновал... его привозил тут сосед, кастрировать жеребенка... Ну и вот подпоил его, когда уж это... Подпоил его, он пьяненькой, тожно видно охота стало ему это, показать фокус-от (смеется)... Ехали оне в кошевке... Вот он ему говорит: “Тебе, говорит, охота фокус увидеть? Ну, Александр Васильевич, охота тебе фокус увидеть? Я, говорит, тебе покажу." “Ну-к, покажи, говорит.” Он, значить, из-под себя взял там соломинку, этот вертинар-от... счас вертинары, а раньше не вертинары назывались... взял из-под себя соломинку, чё-то пошептал на её, и отпустил по ветру! По снегу мальчик маленькой побежал, дак токо вьет, вьет за ём, маленькой парнишко. Вот он налетит, парнишко, на тебя, на меня, и вот и... вот те и пошибка (Смеется).

Иссл.: И как она залетает, как соломинка?

Да не догадашься вовсё!

[I will give you an example. We had a farrier... a neighour brought him over to castrate a foal... And he made him [the farrier] drunk afterwards... Made him drunk, so he was drunk, and he decided to show a magic trick (the informant laughs)... They were riding in a sledge (koshevka)... He [the farrier] said: "Would you like to see a trick? Well, Aleksandr Vasil'evich, would you like to see a trick? I will show you." "Well then, show me" - he answered. He took a straw from under where he was sitting, this veterinarian... they are called veterinarians now, but back then they were not called veterinarians... took a straw from under where he was sitting, 
whispered something over it, and let it go in the wind! A little boy [suddenly appeared] running after him in the snow, and was just running and running after him, that little boy. If that little boy ran into you or me - then you would have a poshibka (the informant laughs).

Researcher: And how does it get inside? As a straw?

Informant: You will never guess!] (N.K.A, female, born in 1919; Siv.; June 2000]

\subsection{How a poshibka enters the body}

A poshibka can fly in through the mouth or nose. In this case a poshibka can have the appearance of an insect (fly, mosquito, midge), or a straw, or speck of dust. The poshibka can enter through other bodily orifices like the ear or eye, or through anal or vaginal openings. In this case a poshibka looks like an insect or is invisible. The poshibka can be imbibed in a drink, in which case it looks like a speck of dust or is invisible.(5) A poshibka ingested with a meal is invisible.

\section{Examples:}

Researcher: And how does it get inside?

Informant: Может комариком залететь, мухой, ну, поперхнулся человек, рот открыл, там муха залетела, особенно без молитвы если вышел утром из дому... Рот открыл - раз, бывало ведь, что комар залетит в рот, муха залетит в рот, ладно, если простая муха, так ещё и выплюнешь, а ту уже не выплюнешь. Она уже попала внутрь. И там растёт

[It can fly in as a mosquito or fly; a person chokes, opens [his or her] mouth, and the fly gets in; especially if [the person] left the house in the morning without saying a prayer... [He or she] opens their mouth... - and there you go. Sometimes it happens that a mosquito or fly gets into your mouth; well, if it's a normal fly - it's okay, you just spit it out, but you won't be able to spit out that one (meaning the poshibka fly). It's gotten inside and it grows there] (Z.A.G., female, 63 years old; Siv.; 2002, recorded by M. Akhmetova and A. Koz'min).

Одна женщина съела ягодку с черемухи. Такая хорошая сделалась, черная ягодка, крупная. И взяла ее и съела. И сразу она услышала, у ей закололо. Это боль была. Потом она через некоторое время стала икать, потом стала говорить, и сказала: “Ты вот ягодку съела с черемухи, вот я и была, в тебя и залезла", - говорит. Сказала.

[A woman ate a bird-cherry. It was such a nice black and big cherry. And she took it and ate it. And she immediately felt pain somewhere inside. That was a poshibka. Then, after some time, she started hiccupping, and then it started speaking, and it said: "You ate the bird-cherry, and that was me, and I got inside you." That's what it said] (V.F.N., female, born in 1922; Ver.; 1999, recorded by I. Kulikova and O. Khristoforova). 


\subsection{Symptoms of a poshibka inside the body}

When a poshibka is inside the body, it causes chest pains; stomachache, headache, limb pain and so on. When it "walks" inside the body it feels like a ball of yarn or a lump. A poshibka can cause fits of hiccupping or yawning. It can prevent people from working, praying, eating certain foods like onions, black radishes, or fish. It can also make a person sleepy or compel a person to eat and drink "what it [the poshibka] needs." It provokes fainting or nervous fits as a response to some situations such as the mention of unpleasant topics or the speaking of unpleasant words. The same reaction can occur in response to unpleasant actions by others of when someone requests fortune-telling. Fainting or nervous fits can occur as a reaction to sudden or threatening situations. A poshibka can talk and tell fortunes. In this case, its appearance is not specified.

\subsubsection{Diagnosing a poshibka.}

A poshibka can be detected by a healer or a doctor during a medical exam. It can then appear as a frog or lizard, or, if it is "in the blood," "everywhere," it can be invisible. The existence of one poshibka can be revealed by another poshibka. It then looks like a human being of indeterminate appearance.

\section{Examples:}

Researcher: Она [пошибка] вам не мешат?

[Does it [poshibka] bother you?]

Informant: Она мешала мне шибко и счас мешат хорошо!

[It bothered me very much, and it is bothering me quite a lot now!]

Researcher: А чем?

[How exactly?]

Informant: Сном мешат. Выпить не дает - ведь как, надо бражку все равно попить. Тоже вот, надо утром, надо вот немножко помолиться всё, кашель, то в горло лезет, лапочкой там царапатся. То сон напустит, то мысли неподобныё).

[It makes me sleepy. Does not let me drink - and you kind of need to drink home brew. Also, it is necessary to pray a little bit in the morning - but no, (it makes me) cough, it gets into my throat, scratches there with its paw. Or it puts me to sleep, or causes inappropriate thoughts (E.A.Ch., female, born in 1932; Siv.; 2003; recorded by N. Litvina and O. Khristoforova).

Говорящая тоже была. А тут стали исповедь читать - не дает читать. Маленько читат-читат - вот не станет давать читать. Вот это... захватит горло, не может говорить. А Матрена Васильевна-то, вот она говорит - 
Кукушкин дала ему имя - “Кукушкин, дай, болтушке-то продышаться надо, почитать надо, давай!” Отпустит!

[It was a speaking one [poshibka]. They started the confession - and it wouldn't let [them]. [Someone] would read for a little while - and it would not let them read [further]. It's as though... it gripped someone by the throat and [they] couldn't talk. And Matrena Vasil'evna, who called him [the poshibka] Kukushkin, said: "Kukushkin, come on, a chatterer needs to recover her breath, and she needs to read, come on!" And then he would loosen his grip! (E.A.Ch., female, born in 1932; Siv.; May 2000; recorded by N. Litvina and O. Khristoforova).

У сестры у меня была свекровка, у ей пошибка-то посаженна была, шибко уж вино любила пить. Дак у-у-у она, начнет ругаться да матькаться дак... “Ты, хозяюшка, сама дак пьеш вино, меня дак не поишь, задавлю тебя, задавлю и всё!” (Смеется).

[My sister had a mother-in-law, who had a poshibka, and she liked to drink wine a lot. And she [the poshibka] used to start cursing and swearing... "You, hostess, drink wine yourself, and do not offer me anything; I will strangle you, strangle you!" (The informant laughs)] (N.K.A, female, born in 1919; Siv.; June 2000).

А вот ведь она начнет... Луку нельзя мне вовсе есть, вовсе не дает. А вот так охота стало, взяла сёдни постряпала. 12 пирогов. Один пирог съела, ну она у меня везде заходила-заходила. Заходила везде, всё те есть-то, всё. Я еще... съела, ну, она мне тогда руки-ноги отняла, и все... Ходить не могу и сидеть не могу

[And it [the poshibka] would start...I cannot eat onions at all; it would not let me at all. And one day I had a craving, and I cooked twelve pies. I ate one pie, and she [the poshibka] started moving inside, up and down. And once she started moving, it was like [a sign] to stop eating [that food]. I ate... again, and then she [the poshibka] deprived [me of my ability to move] my hands and legs, and that's it. I can neither sit nor walk (S.F.V., female, born in 1907; Ver.; 1999).

А которые-то щуку не любят есть, рыбу. У щуки-то крест есть в голове, а она не любит это, с крестом щуку есть.

[And some [poshibkas] do not like it when you eat pike. A pike has a cross on its head, and they [the poshibkas] do not like that - eating a pike with a cross (V.F.N., female, born in 1922; Ver.; 1999; recorded by I. Kulikova and O. Khristoforova).

Researcher: Можно ли выгнать пошибку?

[And can you chase a poshibka out?]

Respondent: Нет. А я тожно скоко раз ездила, одумалася дак. Дескать, поздно, у тебя уже она в крови, эта пошибка. У тебя уже стала в крови, и ее не выгнать, ты умрешь

[No. I went many times [to the specialists]; [and then] changed my mind. It is too late, [they said], she [the poshibka] is already in your blood; it is impossible to chase her out, [because] you will die] (A.A.P., female, born in 1927; Ver.; June 2000). 


\subsection{How a poshibka exits the human body}

A poshibka can be expelled from the body by a sorcerer and by means of a healing ritual. It can be delivered like a child, in which case, it looks like a fish, a piece of meat, or something weird like a rolling-pin, with heads on both sides. It can "have eyes all over" or look like something "silvery." It can exit through the mouth as a frog; frog or fish caviar, or a crow. It can be cut out during a surgery. In this case its appearance is not clear. A poshibka can be destroyed by burning it in a stove with the oven door shut. The "Resurrection [voskresnaia]" prayer must be recited while this is being done. A poshibka exits the body before a person dies. Its appearance in such cases is not specified.(6)

\section{Examples:}

А вот отец сказывал у меня, кто-то вот тут лечил. Их выгоняли в бане и закрывали в туесок. Она такая как будто серебристая. И в этой бане ее обмывают и с воскрёсной молитвой так и сжигали ее тут.

[My father told me that someone here used to heal [people from the poshibka]. [The poshibkas] were chased out in a bath-house and captured inside a birch-bark vessel (tuesok). She [the poshibka] is sort of silvery. And she is washed and burnt in that bath-house while [someone] recites the Resurrection prayer] (P.M.M., female, born in 1921; Ver.; June 2000).

Вот у нас была Матрена Понифентовна, у ей, видимо, тоже была болезнь. Она говорит, лечилася какими-то способами. И она ее родила. Родила, говорит, кусочек мяса. Взяла его, говорит, завернула в платочек, в тряпочку белую, и положила за печку. Утром встала, посмотрела: там ничего нету, только кровяное место. Она снова ушла. Надо ее сразу было сжечь с воскрёсной молитвой или с какой-то молитвой, чтобы у нее она не была, а она ее оставила. Значит, с пошибкой умерла

[Then there was Matrena Ponifentovna and she, probably, also had the illness [bolezn']. She said that she tried to heal herself in various ways. And she gave birth to it. She said she gave birth to a piece of meat. She took it, wrapped it in a handkerchief, a white cloth, and put it behind the stove. In the morning, she got up and looked but there was nothing there, just a bloody spot. [The poshibka] had escaped. She should have burned it immediately, while reciting a Resurrection prayer, or some other prayer so that [the poshibka] would leave her. As a result she died with the poshibka] (V.F.N., female, born in 1922; Ver.; 1999; recorded by I. Kulikova and O. Khristoforova).

У тетки Минихи была пошибка тожо, а Полит ее лечил, она, говорит, вылетела, как ворона, захлопала, захлопала за печкой... Пошибка. Как ворона, говорит, вылетела. Это тетка Миниха рассказывала сама. Я, 
говорит, заухала: “Полит, Полит, иди-ко сюды, иди-ко сюды!” А он пришел, говорит: “Дак зачем ты огаркала-то, не надо было огаркать-то!” А потом она обратно зашла. Он ей только заглушил, а не мог выгнать больше

[Aunt Minikha also had a poshibka, and Polit cured her; she said she [the poshibka] flew out [of her] as a crow, and flapped and flapped [its wings] behind the stove... It was the poshibka. She flew out as a crow, she said. Aunt Minikha told me this herself. She said that she moaned: "Polit, Polit, come here, come here!" And he came and said: "Why did you shout; you should not have shouted!" And she [the poshibka] entered [her] again. He only muted it (or quieted it down), but could not exorcize it (T.I.M., female, born in 1932; Siv.; June 2000; recorded by E. Lopatina and O. Khristoforova).

Вот, вырезают в больницах эти, киста называется. Она всяка бывает, разная, вот, может слыхали? И с глазами, и волосата, там страшно, страшно, всякие виды, всякие виды, человеческого образа и всяко-всяко бывает. Вырезают. Дак вот я считаю, что это и есть, она и есть, пошибка [[They] remove it [surgically] in the hospital, what they call a cyst. It can be of various kinds, different kinds; maybe you've heard about it? [It can have] eyes, hair; it is terrible, terrible, all kinds of appearances, [it can have] a human appearance, and comes in all kinds of different forms. [They] remove it. And I think that this [cyst] is it; it is a poshibka (D.O.K., female, born in 1946; Siv.; 2002; recorded by M. Akhmetova and A. Koz'min).

У кого-то тоже была пошибка. Лечили врачи, пытались даже узнать чтото, ей предложили операцию, женщине. В Перми. Какой-то профессор за это будто взялся. Ну и оказалось, что разрезали, а ничего не нашли. А потом что-то там всё-таки вынули, в спиртовый раствор, там, положили, в это, всё. А потом у профессора изо рта она кричит. Да матом ругается. “Ах ты, такой-сякой, мать-мать! Хотел меня угробить, да я тебя вперёд упеку!" И вот, что-то, видимо, во время операции, что ль, она залетела [Someone also had a poshibka. Doctors tried to cure it, tried to find something out about it and suggested that the lady have surgery.

[It happened] in Perm'. Some professor, a medical luminary, decided to operate. And it turned out that, when they opened her up, there was nothing inside. But then they took something out after all and put it in formaldehyde. And then she [a poshibka] started shrieking out of the professor's mouth. And she was using foul language: "You so-and-so, damn it! [You] tried to kill me, but I will finish you first!" Something like, it seems that it entered him during the surgery] (R.A.G., 74 years old; Siv.; 2002; recorded by M. Akhmetova and A. Koz'min).

At the same time, the above-mentioned motifs are not isolated and can be easily contaminated by others.

For example: 
Хм! Колдуны-те черномазию-ту читают-читают, мальчиков-девочек нас наделают, и вот мы оживём, выпустят нас 40 штук, ох, мы и верти́мся, бегам, бегам, бегам, бегам, веселимся, на воздухе-то. А потом в кого надо, в того залезем. Или комаром, или воздухом, или мухой, как могут. $[\mathrm{Hm}$ ! The sorcerers read various black magic books and create us, girls and boys; and we become alive; [they] let us go, about 40 of us; and we spin around, and run, run, run, and run and have a jolly time out in the fresh air. And then we enter those whom we are supposed to (possess). [We enter in the form of] a mosquito, air, or a fly; in all possible ways (E.A.Ch., born in 1932; Siv., June 2000).

Researcher: Don't poshibkas die?

Informant: А они чё, бестелесные дак... Адская сила [Why would they; they have no bodies, therefore... [They are] the power of hell].

Researcher: Yet they have some physical appearance when they can be exorcized.

Informant: Ну. А их рожают, говорят, как вот пирожник, вон тесто скёшь, и все в глазах кругом. Вот рожала женщина, я слышала. Родит как ребенка, токо небольшая, как в глазах, говорит, вся. В глазах

[Well. They are delivered, they say, like a rolling-pin (pirozhnik) when you prepare dough, and there are eyes all over it. I heard that one woman gave birth. It was born like a baby but tiny and [there were] eyes all over it. Covered all over with eyes (E.A.Ch., born in 1932; Siv.; May 2000; recorded by N. Litvina and O. Khristoforova).

All of the above indicates a poshibka has no one specific appearance: essentially it is amorphous, unclear, or it looks like a chthonic animal or an insect. The crow can also be added to this list. The tradition bearers see no contradictions here, since shape-shifting is characteristic of evil spirits. Ideas about the appearance of the poshibka, like beliefs in supernatural beings in general, have two different sources. The first is found in Christian books like the Holy Scriptures and Orthodox hagiographies where demons are mentioned often but the topoi of their appearance are not articulated. The second source is local mythology, which is, probably, Finno-Ugric, Komi, and Komi-Permiak in origin. This mythology describes the poshibka in very concrete and detailed terms. Another characteristic of local belief is that the poshibka is not seen as purely negative.

The question about the source of specifically Russian ideas about possession cannot be answered using the material presented here. It is only possible to state that ethnographic data show that similar beliefs are not attested among the South or West Slavs or among the Ukrainians and Belarusans. Only if we include all cases of personifications of disease as malicious agents getting inside humans and eating them from inside can we speak of analogous possession beliefs among other Slavs. 
Klikushestvo a phenomenon widespread among the Slavs [Murdock 1980: 49; Vinogradova 2000: 289-301] is analogous to poshibka. But klikushestvo is a phenomenon separate from other illnesses and one that was heavily influenced by Christianity and Holy Scripture. At the same time, klikushestvo and poshibka are semantically different concepts; they are two independent socio-cultural phenomena; they should be viewed as two "dialects of possession."

Poshibka is unique because it likely originated in Komi mythology. What points to the possible genesis of the poshibka from Komi belief is the similarity between many motifs found in memorates about the poshibka and the features the Komi-Permiak being called the sheva. The word 'sheva' comes from the pra-Permian *šo-u-a meaning "something with a voice, sound, message" < šo "voice, sound", Komi-Zyrian "shy" meaning "sound", shyavny - "to sound, produce sounds, speak, to speak up" [Napol'skikh 1999: 45-48]. The word "sheva" has two meanings: 1) a spirit that gets inside a human disguised as a lizard, winged insect, worm, larva, hair, speck, or a knot on a thread and causes various pathological reactions; 2) the pathological state itself. The Komi people thought that the masters of the sheva were sorcerers who acquired the sheva at the same time as they acquired their knowledge of sorcery. There was also a belief that sorcerers created the sheva from twigs that had come loose from a stove broom, from ashes, from sweepings, or from parts of a lizard dried and ground into a powder. The sheva that was prepared in this fashion was kept in a birch bark basket (kuzovok), in a cellar (podpol'e) or in a barn. The masters of the sheva had to feed it meat and milk every night and to keep it busy, eventually giving it away secretly to other people. It was thought that it was easier to give the sheva to those who violated behavioral norms. For this reason sorcerers put the sheva into a drink or a meal in the hope that a person would forget to make the sign of the cross before eating. They were also said to leave the sheva on the house porch, on the stairs of a barn, at a crossroads, on fence poles, or on an uneven road, that is, in such places where people were likely to curse as the result of stumbling or tripping, or overturning a wagon. People also thought that a sheva in the form of a lizard could creep inside a person sleeping on the ground.

It was believed that once the sheva got inside a person's body, whether by means of a meal, a drink, or through the air, it moved around, gnawed on the tastiest tissues and ultimately became covered with hair. There are cases when a person perceived the sheva as a crow or cock and, during fits, would imitate that bird's behavior. Many chronic 
diseases accompanied by suffocation, chest pains, stomachache, or headache were thought to be caused by a sheva. Yet the main symptom of the sheva was considered to be periodic histrionic fits, actions and speech that had not been typical of the person prior to affliction; possession, thus, appeared as a split in the individual's consciousness. Those who witnessed sheva fits described how an absolutely healthy woman would suddenly get headaches, lose her appetite, and how some trifling matter would cause her to have the epileptic-like seizures. After the fit, the woman would become euphoric and start prophesying in a curt and shrill voice, speaking on behalf of the sheva inside her. Those who were present could ask questions and find out the name of the sheva's master, as well as answers to their own or their relatives' questions about the future and about missing objects and animals. The Komi-Zyrians believed that the speaking sheva originated from a lizard's head unless a sorcerer, to protect his identity, tied the sheva's tongue with a horse hair. It was possible to provoke a sheva by an unpleasant scent, with sour or bitter food, by showing the afflicted person a worm, burbot, or something rotten. It was possible to call forth the sheva by gaining its favour with nice conversations, compliments, and promises to satisfy all the sheva's whims. During World War II, villagers used the abilities of the possessed to foresee the future. Thus they purposefully provoked a fit in a woman in order to get information from a spirit inside her about the fate of the soldiers who had stopped writing home.

According to the folk point of view, the sheva stayed inside a person until his or her death, and then it would get inside another person. At the same time, people believed that the most powerful sorcerers were able to exorcize and kill a sheva with the help of special magic rituals and herbs. Although the sheva could not be hurt by a knife, it could be sewn inside a small leather sack and cast into a fire where it would burn up, making loud crackling noises (Mifologiia 1999: 382-382; Sidorov 1997: 106138).

Despite the similarity of these beliefs to the mythology of the Verkhokam'e, the nature of the latter is syncretic, combining indigenous motifs with Christian ones. Even so, the mythological syncretism of the Old Believers is not homogeneous: at one extreme, among secular people (mirskiie),(7) we encounter poshibka narratives that have nothing to do with the Christian worldview and lack any hint of an Evangelical approach to the phenomenon. Quoting an informant: "А кто её знат, кто там" [Nobody knows what it is]). At the opposite extreme, there are 
pronouncements, especially by sobornye (church women), which clearly link the poshibka to ideas found in the Holy Scriptures:

Researcher: And where does a poshibka come from?

Informant: Не знаю, дескать вроде бес там сидит. В человеке. Ну, это в Писании есть, что беси в человеке сидят... Даже Господь по земле когда ходил, тогда тоже бесноватые были. Господь из одной выгнал семь бесов. Книги надо читать, будешь всё знать

[I do not know, it is kind of a demon sitting there. Inside a person. According to the Scriptures, the demons are inside a human... Even when Jesus lived on earth, there were possessed people back in those times. Jesus cast out seven demons from one [woman]. You should read the books, and then you will know everything] (A.K.B., born in 1921; Ver.; June 2000).

А в Евангелии-то сказано ведь - вот из одного человека выгонят пошибки-те, они летают-летают-летают, она как, человека-то не мучит, дак она... Он пуще даже молится, все, чисто, она ходит, летат-летат, невидимо оне дак, а потом не найдет в кого полизти - обратно воротится и уже семь бесов с собой ведет. На человека-то пущено. В Евангелии сказано.(8)

[It is told in the Gospel how the poshibkas are cast out from a man; they fly, fly, and fly; if she [the poshibka] does not torture a man then she... He [a man] even prays more, and she walks, flies and flies invisible, and then, if she can't find anyone to get inside, and she then returns with seven more demons. They are set loose on a man. This is as it is told in the Gospel] (E.A.Ch., female, born in 1932; Siv.; 2003; recorded by N. Litvina and O. Khristoforova).

Therefore, we can conclude that the poshibka concept itself and the detailed semantics of its character come from Komi mythology. Only the image of a lizard has been lost in the new cultural setting. In the Old Believers' context, poshibka ideas have been made consistent with Christian literature and with the social-psychological functions that Verkhokam'e culture requires.

\section{Name of the poshibka}

If a poshibka is a speaking one then it usually has a name and sometimes even a patronymic; and it is believed that the spirit chooses its own name. As a rule, the name is of a masculine gender. Attested ones include: Vasilii Ivanovich, Fedor Ivanovich, Semen Ivanovich, Vas'ka, IErma (a diminutive from Eremei). Female names occur as well and the ones attested here include: Marina Nikolaevna, Sima, Aksin'ia, etc.:

Researcher: And who names [a poshibka]?

FOLKLORICA 2010, Vol. XV 
Poshibka: Василий Иванович, да! [Vasilii Ivanovich, yes!]

Researcher: And who gave it this name?

Female informant: Сама, сам! [It itself!]

Poshibka: Василий Иванович я! [My name is Vasilii Ivanovich!]

Female informant: Это не я назвала, она сама называт [I did not give it this name, she [the poshibka] named herself] (U.F.F., female, born in 1931; Ver,; 2002; recorded by V. Kostyrko, A. Rafaeva, and O. Khristoforova).

Researcher: How did you find out his [the poshibka's] name?

Poshibka: Да вот... [Well...]

Informant: Сказыват он [He speaks].

Poshibka: Да Федор Иванович я, Федор Иванович. Я Федор Иванович...[ I am Fedor Ivanovich, Fedor Ivanovich. I am Fedor Ivanovich...]

Informant: Вот видишь, говорит [You see, [he] speaks] (M.I.V., female, born in 1938; Siv.; June 2000; recorded by E. Lopatina and O. Khristoforova).

У нас там в деревне была, я еще в ребятах была, старуха... не старуха, она женщина такая могутная была... Вот какая-то пошибка у нее стала. «Я, - говорит, - Семен Иванович, вот в чумашке рос

[When I was still a child, there was an old woman in my village... not really an old women, she was very robust... And she got a poshibka. I, - it said, am Semen Ivanovich; I grew up in a birch-bark vessel (chumashka) (I.K.G., female, born in 1926; Ver.; 1999).

The fact that a poshibka has a name prompts some researchers to connect this supernatural being to the so-called zalozhnye (unquiet) dead, i.e. people who died a "bad" death or a death that was "not their own." Such people must live out the rest of their allotted time on earth and their spirits try to assume a bodily form (Vinogradova 2000: 298-301). This hypothesis is simple and elegant. It explains why the poshibka names itself and it accounts for the strange monologues that the poshibka is often said to deliver. Unfortunately, this explanation is impossible from the point of view of Old Believer faith and is does not fit with the Christian view of the afterlife. For Old Believers, spirits that get inside humans as well as the "walking dead" (often encountered in Verkhokam'e bylichki [memorates]) are nothing other than evil forces. In the case of the walking dead, they are evil spirits who assume the appearance of the dead. Evil spirit beliefs are likely of more recent origin since the sheva is connected to neither the cult of the dead nor the afterlife in the pagan mythology of the Komi. It appears that the Komi perceive the sheva as associated not with the world of spirits, but with the real world of animals, objects, and substances used by a sorcerer. This presupposition is confirmed by contemporary studies of Komi mythology. P. F. Limerov, for example, does not mention a sheva among 
either evil spirits or beings from the world of the dead, but characterizes it as a mythical being sent out by a sorcerer in the tangible form of a lizard or insect (Limerov 1998a: 79; 1998b). A significant sheva monologue was recorded in the Komi-Perm' district. In it, a Russianspeaking female, about 60 years old, speaks in a high pitch and while breathing in:

Я вить не человек. Меня зовут хоть Валерий Андреич Рубино́в, я вить ящерица. У меня еще и подруга есть, Таня, она лягушка. Я не мешаю, хозяйку не обижаю. У меня хозяйка очень хорошая. Я не хулиганю, табак не курю. Когда уснет, удираю к подруге. Приду и захожу холодный (проводит правой рукой от горла к животу). У меня подруга-то лягушка. Уснет, я иду, хоть пурга, хоть что. Однажды чуть не убил меня ветер. Я под кусты сел, сидел, холодный пришел, у хозяйки рот открыт, она проснулась - холодный, холодный (снова проводит правой рукой от горла к животу)(9)

[I am not a human. Even though my name is Valerii Andreich Rubinov, I am in fact a lizard. And I have a friend, Tania; she is a frog. I do not bother my hostess, do not hurt her. My hostess is very nice. I do not make a row; do not smoke tobacco. When she falls asleep I sneak to my friend. I return cold and enter [her] (informant shows how by moving her right hand from her throat down to her belly). My friend is a frog. When [the hostess] falls asleep, I go [to my friend] no matter if there is a snow storm or something else. Once, the wind almost killed me. I sat down under a bush, and was sitting [waiting]; [I] came back cold; the hostess was sleeping with her mouth open, and she awoke - I was cold, cold (informant does the same movement again, with her right hand going from her throat down to her belly).

\section{Gender of the poshibka}

The fact that klikushestvo is primarily a female phenomenon was recognized a long time ago. P.S. Efimenko discovered a court case about klikushi in the Arkhangel'sk archives dating back to 1785 and the opinion of Veniamin, the Archbishop of Arkhangelsk and Kholmogory, was attached to the case. According to this document, the Archbishop thought that possession in the Pinezh district was caused by the stagnant water, which the peasants used for their needs: "которыми водами люди питаясь, не получают ли в себя семян или зародышей таких червей, которые зародясь в их желудках, болезни те производят?” [ . . by consuming such water, would not people get the seeds or germs of such worms that, being conceived in their stomachs, would cause those diseases?]. To him, bad water helped explain the gender differences in found in possession, namely that women's stomachs were weaker, making the onset of disease easier. In men, he thought, "from either 
[hard] work or [the consumption of] the strong beverages... [germs of worms] perished straight away" (Efimenko 1864: 85). The Komi people, though they did not use such explanations, also believed that women (especially those pregnant and immediately post delivery), young girls, and old spinsters were at a much higher risk of contracting the disease than men. At the beginning of the $20^{\text {th }}$ century, in some districts, it was believed that only an exceptional woman could avoid being infested by a sheva, since women got it right after marriage. Men, they thought, would die quickly upon contracting a sheva (Sidorov 1997: 107).

Gender differences are preserved in the Verkhokam'e: the majority of the poshibka bearers are women. A reverse correlation exists in that the poshibka is typically given a male name. During my fieldwork I encountered only one text about a poshibka in a man. The text differed from those about a poshibka in females and was rather a story about demons tormenting a sorcerer. Informants usually either stated that the poshibka did not occur in men or assumed that it was possible, but could not remember any such cases:

Researcher: And can the poshibkas get into a male?

Informant: Попадают [They can].

Researcher: Even into males?!

Informant: Но это, по-моему, очень редко, у мужиков. Обычно у женщин почему-то, я не знаю [But this, I guess, rarely happens with men. Mostly they get into females, I do not know why].

Researcher: And do you know of a case when it got into a male?

Informant: Угу. Кто же мне рассказывал, что вот мужчине попала... Но обычно почему-то всё у женщин [Yeah. Someone told me that it got inside a man... But usually it mostly happens with women] (L.N., female, born in 1953; Siv.; June 2000).

I have encountered only one explanation for this: “Женщина ee может родить. Полечится, она ее родит" [A female can give birth to it. She will get some cure, and will deliver it] (V.F.N., female, born in 1922; Ver.; 1999; recorded by I. Kulikova and O. Khristoforova). This explanation recalls the Komi belief that a man dies quickly once infested by a sheva, but it does not explain why a poshibka gets primarily into women in the first place. Let us examine the problem further.

8. The pragmatics of the poshibka concept

8.1 The victim 
There is a belief in the Verkhokam'e that a poshibka usually gets into women of childbearing age and seldom enters young girls, even though such stories do exist and have been recorded by the author. A poshibka can reveal itself immediately, in which case the afflicated person would feel pain, heaviness and would have fits of nausea or fainting. But sometimes it can reveal itself only much later when, all of a sudden, the poshibka begins to talk. One female informant learnt that she had a poshibka when she was 50, and only when a poshibka of another woman told her: "Тебе на семнадцатом году на красном яблочке села и залетела [When you were seventeen, [a poshibka] was sitting on a red apple, and flew inside [you]]" (E.A.Ch., female, born in 1932; Siv.; 2003; recorded by N. Litvina and O. Khristoforova).

Oral tradition provides several reasons why a poshibka gets inside a human. According to the most widespread one, the victim is to blame and such texts have an obvious edifying function. The person may be the victim of a sorcerer, but her own fault is one of two kinds: she can transgress religious norms by swearing or not wearing a cross, by not praying when entering a yard, a house, at a crossroads, or before eating. The other fault is disregard of the norms of social interaction, especially interaction with a sorcerer, and can include behaving imprudently or immorally and angering other people:

А была в Трошино Марья Ивановна, вот ей пошибка попала дома в огородце. Она потом заговорила у неё! Она долго маяла ее, много годов. Потом заговорила: “А чё, чё ты меня не любишь, чё ты меня выживашь? А я была на тебя излажена. Вот я на тебя была отпущена”. А вот не сказала, кто пустил. Не сказала. И как допытывали, и как уж спрашивали, никак не сказала. Не созналася, кто ее пустил. "Я на огороде сидела,- говорит, - не один год тебя ждала, когда ты пойдешь без молитвы. И вот ты, - говорит,- шла, ругалася, - она на ферме тоже работала со мной дояркой, - ты шла по огородцу и ругалася. Ох, я и с колышка в тебя и заскочила! Я сидела на колышке. Ты пришла домой, о-ой, захворала. Ой, заболела голова! Вот ты сутки пролежала, даже на работу не пошла, а потом ты захворала-захворала, и вот ты сколь-то похворала, тебе стало легче, я маленько отступилася от тебя. Леготу тебе дала. Ты поработала на ферме - опять заболела! Ты потому что меня начала мучить в работе.” Да-а! Вот она маялася

[There was Mar'ia Ivanovna in the Troshino [village]; and a poshibka got into her when she was in her garden. And she [the poshibka] later started talking! She [the poshibka] tormented her for a long time, for many years. And then she started talking: "Why don't you like me; why are you trying to drive me out? I was created for you. I was sent to you." But she did not say who sent her. Did not say [that]. And no matter how hard they interrogated her and asked her - she did not say. She did not confess who sent her over. "I was sitting in the garden, - she said, - waiting for you for several years,

FOLKLORICA 2010, Vol. XV 
waiting when you would go without a prayer. And here you were, - she said, - cursing (she was working with me on a farm, as a milkmaid); you were walking around in the garden and cursing. Oh, I jumped right into you from a pole! I was sitting on a pole. You came home, oh-h, and got sick. Oh, [your] head was aching! You were lying for a day, did not even go to work; and then you became very sick; and after you were sick for so long you felt better [because] I eased up slightly. [I] gave you some relief. You went to work on a farm and then you became sick again! It's because you started tormenting me by your work." Yes! That's how she [Mar'ia Ivanovna] was suffering] (I.F.M., female, born in 1919; Ver.; June 2000].

Researcher: What was your fault?

Informant: Кто его знат? Гуляла шибко уж я, перебирала мужиков. Кому-то, может, досадила [How would I know? I used to fool around, flirt with lots of men. Maybe one of them was hurt] (M.I.V., female, born in 1938; Siv.; June 2000; recorded by E. Lopatina and O. Khristoforova).

It is believed that sorcerers can spread a poshibka in two ways. They can target it at a specific individual, sending it to the person who angered either them or their clients, or they can disperse it in an un-targeted way, "through the air," since they must spread the demons that compel them. Upon the death of its host, a poshibka becomes independent and can decide its own fate.

Informant: А они ведь, как умрет человек-от, дак они выходят тогды [When a person dies, they [the poshibkas] exit then].

Researcher: And what happens then?

Informant: Ну чё, выходят, заходят тому, кого она любила, тому и заходят [Well, they exit and then get inside a person she [the deceased] loved; that's where they go] (A.N.B., female, born in 1912; Siv.; May 2000; recorded by N. Litvina and O. Khristoforova).

An example of the edifying function can be found in the following text:

Пошибка тоже говорящая была: “Я, - говорит, - хозяюшку задавлю, задавлю, задавлю.” "Нет, не задавишь." "Нет, задавлю.” “А куда ты пойдешь?” “Я пойду на речку, сяду на речку, какая девушка молоденька придет воду черпать, перема́тькатся, я в нее полезу”

[There was a poshibka who could speak . "I, - it says, - will finish, finish, finish off my hostess." - "You will not." - "Yes, I will." - "And where will you go [after that]?" - "I will go to the river, will sit in the river; when a young girl comes to fetch water; she will curse, and I will get inside her] (E.A.Ch., female, born in 1932; Siv.; May 2000; recorded by N. Litvina and O. Khristoforova). 


\section{Spirit Possession in a Present-Day Russian Village}

Она залетает, говорят, когда ей вольготно жить в которой будет [Theу say, she [the poshibka] flies inside a female in whom she find freedom] (R.A.G., female, 74 years old; Siv.; 2002; recorded by M. Akhmetova and A. Koz'min).

An interesting text describes a poshibka who chooses the victim itself, against the will of a sorcerer who sent it:

“Меня зовут Марина Николаевна, я Мариночка. Я ведь не в старуху пушшена была, а меня... пушшена была я в Оринку." У ее соседей дочь Орина была, у нее тоже пошибка была. Вот она: “Да чё я в ёй полезу, старик у её, да седой, да с бородой... Я Мариночка-девочка. А старухато Богу молилася, а я ей в ухо полезла"

["My name is Marina Nikolaevna; I am Marinochka. I was not sent into this old woman, but I... I was [initially] sent into Orinka." Her neighbours had a daughter, Orina; she also had a poshibka. So she [poshibka] said: "Why would I get into her [Orina]; she has an old man; he is grey-haired and has a beard... I am Marinochka the girl. And the old woman was praying to God, and I got inside her through her ear] (E.A.Ch., female, born in 1932; Siv.; May 2000; recorded by N. Lapina and O. Khristoforova).

The material above indicates a pattern: according to the bylichki (memorates) recorded, if a sorcerer sends a poshibka, then the narrator presents the victim as innocent; but if a poshibka acts as an independent agent, then the victim is somehow at fault. Children, adolescents, and females who get a poshibka by mistake, something that can happen if the unintended victim has the same names as the intended one, are described as innocent. In all other cases, the victim is considered to be at fault. This fits the Christian understanding of diseases and misfortunes as consequences of a sinful life and it fits the didactic-pragmatic function of poshibka stories. Even those stories that assign some degree of blame to the victim, however, tend to treat the person sympathetically based on the belief that you cannot "protect yourself" from a poshibka:

Researcher: How can a person protect herself? If a person would go around with a prayer, will it [the poshibka] get inside her?

Informant: Так они опять снизу лезут! Вот одна старушка была... у её говорящая тоже стала пошибка-та: “Дак хозяюшка-то на сарай лезла, ей в рот-от нельзя полизти-то- молитву творит - дак я ей снизу полезла" [They can still get inside from below! There was an old woman... she also had a speaking poshibka: "When the hostess was climbing up in a shed - I could not get inside through her mouth, since she was reciting a prayer, so I got inside her from below"] (E.A.Ch., female, born in 1932; Siv.; May 2000M; recorded by N. Litvina and O. Khristoforova). 
From my own observations, I can infer that those female narrators who did not have the poshibka themselves were the most critical of victims while those who suffered, especially without cause, tended to be most sympathetic. There is yet another explanation according to which God allows the devil to enter a human in order to test his/her humility or strength of faith. I encountered this opinion, one derived from the Old Testament (cf. Job) only once. Therefore I treat it as optional for the oral tradition of the Verkhokam'e, where two other reasons for contracting a poshibka dominate. To reiterate: reason one is that demons force sorcerers to inflict this malady and reason two is that humans bring this misfortune upon themselves through their own sins. These two opinions do not contradict each other, as it might seem at first, but rather complement each other. This attitude allows for the coexistence of various interpretations of the same event, an option that is very important for everyday life in the village. Multiple or alternative causes of possession are reflected in the poshibka stories themselves, as in the following example:

А эта, в Чуманах Устинька-та была... дак она (пошибка. - O.X.) полезла в её, сказала: “Ты пошла по воду да без молитвы, я не на тебя была сделана дак, вот ты молитву не сотворила, значит, я в тебя и села" [There was Ustin'ka in the Chumany [village]... and she [the poshibka] got inside her and said: "You went to fetch water without saying a prayer, and although I was not created for you; it was you who did not pray, and I got inside you (instead)] (A.I.S., female, born in 1920; Ver.; June 2000).

Narratives about the failure of a poshibka to get inside a human are extremely rare. There is a literary tale entitled "A Thief and Death," (10) where a poshibka appears in a series with Death, a devil, and fever (likhoradka). In oral tradition there is only one attested account of a poshibka's inability to get inside a person and the reason it fails is that person's proper behavior:

Она вот рассказывала... рожёнка была, родила она, вроде... говорит, это, пошла на улицу, забор открывает, там раньше ворот не было, тут это такие... жерди... она открывает, говорит, и молитву сотворила. И, говорит, как корчага... такие раньше были корчаги большие, глиняные... вот, говорит, такой грохот раздался, как корчага разорвалась. И вот прихожу домой, говорит, ну сходила она это... в туалет сходила, прихожу, говорит, вот так и так. “Ой, хорошо что ты молитву, - говорит, - сотворила. На тебя, - говорит, - была пошибка. Если бы ты молитву не сотворила, она бы, говорит, в тебя вошла."

[She told... there was a woman who gave birth... she says [that woman] went out; she opens the fence - there used to be no gates [at that time]; there are

FOLKLORICA 2010, Vol. XV 
some... poles... she opened, - she said, - and recited a prayer. And [it was] as if a korchaga (a big clay pitcher)... once there used to be such big pitchers made of clay... and so, - she said, - there was such a rattle as if that korchaga had crashed and broken. And so, - she said, - I come back into the house well she went to the outhouse, you see - I come back and tell what happened. "Oh, it's good you recited a prayer, [someone] says. There was a poshibka [waiting] for you. If you had not recited a prayer it would get inside you] (A.A.P., female, born in 1931; Ver.; 1999).

The fact that the narratives of this kind are infrequent can be explained, by the fact that a negative didactic narrative is more powerful in this tradition than a positive one. It is also the case that this situation reflects the often pessimistic view of the poshibka phenomenon that is typical even for present-day inhabitants of Verkhokam'e, especially for middled-aged and older women. This pessimism is expressed in the idea that it is impossible to get rid of a poshibka, especially now that "there are almost no powerful sorcerers left." Although there are various opinions about the poshibka and different attitudes towards the possessed in the Verkhokam'e, one of the dominant emotions is fear. Fear of the poshibka can be so intense that some female informants refuse to discuss this topic: "Я не знаю, меня Бог миновал пока от этого, слава Богу, прожила век" [I do not know, God saved me from this so far, thank God, I have lived my life [without it] (V.F.N., born in 1922; Ver.; 1999; recorded by I. Kulikova and O. Khristoforova). To protect themselves, people use various verbal and non-verbal means.

\section{Behavioral patterns}

Stories about a poshibka are supported by various behavioral patterns. Some of them are widespread and are used in interactions with sorcerers. Others are specific to the Verkhokam'e region. Widely occurring practices include wearing a cross on one's body, saying prayers before meals, and praying while fetching water, leaving a house, passing through gates, or walking at a crossroads and other liminal places. The most widespread prayer is the Jesus Prayer (Lord Jesus Christ, the Son of God, have mercy on us). The Resurrection Prayer (May God be resurrected) is also considered powerful, but not many people know it by heart. Other widespread behavioral patters include precautions against sorcerers such as greeting them politely in the street. People also practice sorcerer avoidance, such as not crossing their path and avoiding direct eye contact. At the same time people may practice symbolic aggression against sorcerers, making obscene hand gestures in 
secret and silently reciting incantations against them. The norms of "symbolic hygiene" are also important. These include actions and gestures that are specific to the poshibka concept such as blowing on the surface of a drink to keep from accidentally swallowing a straw or speck of dust. They also include drinking over one's finger or from the handle side of a cup to protect the mouth. Covering one's mouth and nose from insects while working in the field is a common prophylactic practice, just in case one of the insects is a poshibka. Other protective measures are avoiding things or behaviors that might anger a person who has a poshibka and satisfying all of her or his whims. People are especially cautious when a person known to have a poshibka dies.

\section{Social functions}

The poshibka concept fulfills several important socio-psychological functions in the traditional culture of Verkhokam'e, and this fact contributes to the persistence of this concept. The concept offers a familiar model for the interpretation of various physiological states and it provides a behavioral scheme to deal with cases of real illness as well as cases of feigned illness motivated by the desire to be relieved of household chores, to gain the attention of others, or to secure financial gain in the form of a payment for divination. Pains in various parts of the body such as chest pains, stomachaches, and joint pain can be explained by the poshibka concept, as can fits of hiccuping and yawning, tummyrumbling, drowsiness, and excessive appetite. This is especially true for old women.

Урчит, по желудку ходит, урчит. А если спать захотела- ложись скорее спать. А если есть захотела- скорее ешь. А вот когда ей надобно [It grumbles, moves around the stomach, and grumbles. And if she [poshibka] wants to sleep you would immediately go to sleep. And if she wants to eat you eat immediately. Just whenever she wants that] (A.N.B., born in 1912; Siv.; 1999).

Researcher: How does a poshibka manifest itself?

Informant: А чё-нибудь вот не ладится, то есть не ладится, то еще чего. Вот они и говорят, что есть в нас тоже [Well, if something goes wrong, does not go well. Then they say there is [a poshibka] inside us] (M.I.U., born in 1938; Siv.; June 2000; recorded by E. Lopatina and O. Khristoforova).

Interestingly, the bylichki about how a poshibka gets into a human being differ in the stereotypic nature of their plots and motifs and demonstrate a folkloric origin, while simultaneously reinforcing the 
didactic function of the narrative plot. At the same time stories about how a poshibka reveals itself through the behavior and speech of its victim vary considerably from one individual to the next. Such stories can be both informative and entertaining, while also helping to make sense of everyday experience. Stories about behavior are less dependent on traditional folk narrative patterns than stories about infestation and are more open to innovative interpretations and verbal creativity:

\begin{abstract}
Евдокия Нефёдовна была. И вот у нее пошибка тожо: “Старуха-то легет спать, спи-ит, рот-от распялит, я выгляду, - а это, настенные часы, маятник, - сяду на маятник, покачаюсь-покачаюся, фу-р-р токо, улетю. В Москву-то полетю. Как они начальники-те тамо ругаются, поматеряют, говорит, я гляжу-гляжу на их, надоест, улетю, домой прилетю,- а чё, они молнией летают дак, - сяду на часы-те, покачаюсьпокачаюсь, хозяйке в рот полезу, она спит опеть, ничё не слышит" [There was Evdokiia Nefedovna. And she had a poshibka: "The old woman goes to sleep; she sle-e-eps, opens her mo-o-outh, I get outside; there is a wall clock with a pendulum, so I sit on the pendulum, swing back and forth, and fly away. To Moscow. I watch how those government officials fight each other and curse; and when I get bored I fly back home - yes, they really fly like lightening - I sit on the pendulum again, swing back and forth, and get into my hostess' mouth; she sleeps and does not sense anything] (E.A.Ch., female, born in 1932; Siv.; May 2000; recorded by N. Litvina and O. Khristoforova).
\end{abstract}

Beliefs about the poshibka persist because they fulfill social needs. The community needs possessed people because they serve as a kind of investigator of problems. One of the most common bylichka motifs is divination by means of a poshibka. Such divination helps to identify a thief or an arsonist or find a missing person or animal. When problems arise, many local people prefer not to go to the police. Their choice is to consult a woman with a speaking poshibka and they typically view the information obtained from such a woman as reliable. People also go to such women when they have more serious problems and when divination of the future is necessary. Using possessed women for divination is becoming a money-making, commercial institution in urban areas such as cities and towns. In villages, when there are conflicts between individuals, such as those that arise when objects and people go missing, and people consult a woman with a poshibka, the answers that they get promote social harmony. These answers can confirm what the client thought himself or herself ("на кого думаешь, тот и украл" ["the one you suspect is the thief"]). Answers can discourage the person consulting a possessed woman from searching for the guilty person ("найдется" ["it 
will turn up by itself']). Yet even in the latter case, divination via a poshibka removes doubts. It eliminates the fear of condemning someone falsely and takes away the responsibility for making an accusation since consulting a possessed person places the responsibility not on an individual, but on an "institution." This person-"institution" acts on behalf of the community, while personifying that community only partially. Due to his or her special status, such a person also personifies the world of the unseen, whose inhabitants typically possess special knowledge. Folk culture - including contemporary folk culture - has institutions that are synonymic: soothsayers who use beans, cards, and water to make divinations, for example. Yet the poshibka-fortune-teller is considered preferable since it is perceived as an incorruptible institution. In addition, the client and the poshibka-fortune-teller are perceived to have a special bond since they share the role of victim. Sorcerers, though they have special means of divination, are not as close to the client because they have the reputation of being znatkie, (11) practicing both healing and the casting of spells. As such, sorcerers prompt a watchfulness on the part of the client.

Informant: У нас у тетки Паши была икота, болтала так! К ей ходили ворожить во время войны. Вот она рассказывала. Агафья Тихоновна ждет сына, купила чекушку, пришла. "Хм! Это уж пошибка да выпьёт, выпьёт”. (Воспроизводя речь пошибки, М.Л. говорит громче, чуть медленнее, более интонировано, регистр нормальный.) Молчаламолчала, дак: "Охо-хо! Уж и косточки-то твои сгнили”

[Our aunt Pasha had an ikotka - such a chatterbox! During the (Second World) war people came to her for fortune-telling. So she told [us]. Agafiia Tikhonovna was waiting for her son [to come back]; she bought a small bottle of vodka and came. "Hm-m! Oh, the poshibka will drink" (while imitating a poshibka's manner of speaking, M.L. speaks louder, a bit slower, with more intonation, voice register is normal). She [the poshibka] was silent for some time and then said: "Oh-oh! Your bones have already rotted"] (M.S.L., born in 1914; Ver.; June 2000).

Researcher: Has Fedor Ivanovich (a poshibka of M. I. V.) ever told anything to anyone?

Informant: Ну, говорил вот, ну да... Кому правду вот... первого сына в армию отправлять, я ходила там к соседке, и иду, бражкой напилася, бежу домой, и распевает: "Иди быстрей дак, сына-то,-- говорит,- в армию взяли." Прибежала домой, бегом бражку замешала, и этой бражкой его отправляла. А он был в Ленинграде, парень. Вот как, правду сказала.

[Yes, he has... [He told] the truth to some [people]...when my first son was called up for military service, I went to a neighbour, and drank home-brewed beer; and I was running home, and he [the poshibka] was singing: "Go faster; 
your son was called up." I came home, quickly made a home-brew, and I was seeing him [the son] off with that home-brew. And he served in Leningrad, my boy. So, she [the poshibka] told the truth] (M.I.V., born in 1938; Siv.; June 2000).

As research has shown, the third function of the poshibka's speech is to reveal the name of the sorcerer who sent it, thus potentially advancing his reputation (Panchenko 2002: 332-334). According to the Verkhokam'e data this is a secondary function of possession with the main emphasis being on social control, namely edification, instilling religious ideas and behaviors, confirming moral norms and social stratification. In short, the poshibka supports traditional behavior as a whole.

A fourth function of the poshibka is peculiar to the victims of possession. Their state often becomes a means for satisfying sociopsychological needs. The reputation of being a possessed person gives a woman the right to hold an authoritative opinion; it sanctions her words and actions, and gives them a special status. Therefore, as paradoxical as it may sound, the social marginality of this role provides social power. It elevates status and even brings financial gain in the form of a payment for a divination ritual. It can be important for lonely older women who currently constitute almost all poshibka victims.

Finally, the entertainment function of the bylichki is also important. The narratives exist almost as anecdotes in which allow verbal play through the imitation of poshibka speech patterns:

Informant: А вот в этом, в Вяткино-то, я туда ходила за чем-то. С санитаркой идем, зашли к ней, ну, она и рассказывает: "Вот обварила грудь, - говорит, - я.” Ну, мы спрашиваем: “Как обварила-то?” Она говорит: “Да кипяток взяла, - говорит,- вот чугунку, и, - говорит, - както опрокинулась она мне на грудь.” А вот эта икотка-то у ней и говорит: “Косорукая, дак не брала бы!” (Смеется). Быстрехонько так среагировала: “Косорукая, дак не брала бы!” Так интересно

[I was in the Viatkino [village]; I went there for something. I was walking with a nurse: we stopped at her place and she said: "I happened to pour boiling water over my chest." Well, we asked: "How did it happen?" And she said: "I took boiling water, in a cast-iron [vessel?] and somehow managed to pour it over my chest." And her ikotka said: "[If you are] clumsy, you should not have picked it up!" (Informant laughs). And she reacted so quickly: "[If you are] clumsy, you should not have picked it up!" It is so interesting] (A.M.Zh., born in 1936; Ver.; 1999).

For people, especially young people, the very act of communicating with a poshibka provides access to the supernatural that is both a 
frightening and attractive. It is a theater of sorts, an arena in which the young can experiment with the other-worldly.

Yet it is impossible to state that the poshibka concept appeared solely as a response to personal and social needs. The opposite is also true and the poshibka concept reinforces the needs that it satisfies. Furthermore, the concept stems not from social and personal needs alone, but also from folk belief in sorcerers, the moral dualism introduced by Christianity, and cultural relations and exchange with the aboriginal Komi population.

\section{Conclusion}

Doctors became interested in klikushestvo in the second half of the $19^{\text {th }}$ century when it manifested itself in Central Russia through fits during mass and in the presence of sacred objects such as icons, crosses, relics, and holy water. Doctors defined klikushestvo as a type of hysteria - corea magna - that resulted from "psychic contamination" and spread in a patterned way. My data permit me to state that klikushestvo is not a disease with defined symptoms. Rather, it is a model used to explain pathologies that can be as varied as neuroses, skeletal system disorders, and cardio-vascular diseases. It is also used to account for physiological symptoms like obsessive hiccupping and yawning. When describing symptoms, some of which can be very individualized, narrators resort to familiar folklore patterns. The same is true of their accounts of the onset of the disease, and of its diagnoses and treatment. Narrators typically insert new names and details, while reinforcing existing folklore patterns and thus satisfying social and psychological needs. "Possession discourse" in Old Believer circles becomes both a means of explaining various illnesses and a means of manipulating the social environment. It is a "language of power" in a way and a normative institution that confirms the cultural values. Every personal "narrative of disease" emphasizes certain aspects of this discourse, aspects determined by the psychological peculiarities and needs of that person, her family dynamics, her relations with neighbors, and even her response to the researcher.

Narratives about how a poshibka gets inside a human are a way to "externalize" personal suspicions. They can articulate conflicts, even conflicts that occurred long ago. Sometimes narratives can serve as a confession where the speaker admits of lack of foresight, if not sinful behavior. In the view of others, the possessed are those "weak links" in 
the social chain who, at some point in the past, disregarded social norms of interaction, or they were people who could not cope with their own anxiety and the burden of everyday problems. This view offers an acceptable and seemingly rational explanation. It holds that those who were unfortunate enough to find themselves in the wrong place at the wrong time fell victim to merciless fate and internalized evil. In a small village community fate, or dolia, is perceived as a common one, or one shared by all (see Foster 1965). Thus the misfortune of others partially guarantees one's own safety. This is precisely why, at times, another's misfortune evokes unconditional compassion. The possessed who became victims in the most obvious and terrible way, that those with physical disabilities, childless people, alcoholics, and idlers, are seen as people who sacrifice themselves, or are sacrificed, for others. But even this sacrifice is ambiguous for it is both dangerous and contagious. Therefore, communication with a poshibka requires caution, though to a lesser degree than communication with a sorcerer. This social distance, however, does not prevent people from using the possessed for divination, or to address more serious concerns like their own security, or even for entertainment. The "discourse of possession" does not allow one to forget either the "dangerous zones" in space, time, and the social environment or the means needed to neutralize danger.

In sum, the poshibka phenomenon in the culture of the Old Believers is a complex phenomenon where social relations intersect with ideas about the world drawn from Christianity, folk medicine. It is a phenomenon affected by gender and age demographics, by diet, physiology and neurotic fears. The history of the Old Believers comes into play as do the individual histories of contemporary women.

\section{LIST OF ABBREVIATIONS}

Siv. - recorded in the Sivinsk region of the Perm' district.

Ver. - recorded in the Vereshchagin region of the Perm' district.

Kezs.- recorded in the Kezsk region of the Udmurt territory.

\section{NOTES}

1 I would recommend a chapter from a monograph [Nikitina 1993] and two articles from the journal Живая старина [Moroz 1996; Nikitina 1996]. 
2 Over the last two decades, religiosity in Russia has been growing; and the ideas about possession in the form of klikushestvo have tended to spread, especially in the so-called "near-church circles." A study of this process, however, is beyond the scope of my article.

3 Popovtsy is the term used to designate those Old Believer confessions that have a clergy. From the end of the 17 th century to the beginning of the 20t, there also existed a division or confession called beglopopovtsy. These accepted "escaped" or "fleeing" clergy, priests who had been ordained in the regular church but who had decided, for whatever reason, to become Old Believers.

In 1846, when the Bosno-Saraevskii Metropolitan Amvrosii joined the beglopopovtsy, the Belokrinitskaia eparchy was created. At present, it is the Russian Orthodox Old Believer Church.

Other groups of Old Believers, those who never accepted a clergy, are the ones to whom the term bespopovtsy is most widely applied. The largest group of bespopovtsy Old Believers are to be found in Pomor'e.

Belief in the imminence of the kingdom of the Antichrist has lead to the creation of a group among the bespopovtsy who are called stranniki (wanderers). This group of Old Believers consider it necessary to flee the kingdom of the Antichrist and to hide from it. Stranniki do not hold passports. They refuse military service. They do not pay taxes. Some even avoid money altogether. Some beglopopovskie groups of Old Believers who were unable to find priests in the 19th and 20th centuries became de facto bespopovtsi. This is the case with the Chasovennii confession.

4 For other explanations of trance and possession current in contemporary anthropology and the psycho-physiological mechanisms that accompany them see (Prince 1968; Bourguignon 1976; Sharp 1993; Lewis 2003; Ward and Beaubrun 1980).

5 There is some correlation between this popular motif and the custom of treating a guest in one's home, be it a person who is known to the host or a stranger, to home brew or kvass.

6 In the Russian North as well as in the Komi-Permiak tradition, according to the data collected in the 19th -beginning of the 20th centuries, an ikota could have the appearance of a frog, worm, spider, or mouse.

7 Sobornye are the members of the praying commune who adhere to very strict everyday taboos. Usually this means that they can read and write in Church Slavonic. Mirskie are people of the world, those who do not belong to the commune-sobor. 
8 This is a paraphrase from the New Testament: "Now when the unclean spirit goes out of a man, it passes through waterless places seeking rest, and does not find it. Then it says, I will return to my house from which I came; and when it comes, if it finds that place unoccupied, swept, and put in order. Then it goes and brings along seven other spirits more wicked than itself, and they go in and live there, and the last state of that man becomes worse than the first" (Matthew 12: 43-45).

9 The documentary "The Blooming of the Fern" was created in 1995 at the Sverdlovsk cinema studio by N. Okorokova, script writer, and A. Anchugov, producer. The precise place of filming and the name of the informant are unknown.

10 SUS K1 637: a thief who sneaked into a house together with Death, the devil or likhoradka (fever), wishes health to the master of the house when he sneezes. In this way he saves the master and gets rewarded for his actions.

11 In the Verkhokam'e, the word "znatkoi" which comes from "the one who knows" (знающий, знахарь) is a synonym of the word "sorcerer."

\section{BIBLIOGRAPHY}

Andreski, S. 1989. Syphilis, Puritanism and witch-hunts: historical explanations with a forecast about AIDS. London: Macmillan.

Belo, J. 1960. Trance in Bali. N.Y: Columbia University Press.

Beliaev. I. S. 1905. Беляев, И. С. "Икотники и кликуши. К истории русских суеверий. По архивным источникам" [Ikotniki and klikushi. Towards a History of Russian Superstitions. Based on Archival Sources], Русская старина 122(4): 144-164.

Bleikher, V. M. and I V. Kruk. 1995. Блейхер В.М. и И.В Крук. Толковый словарь психиатрических терминов. [Comprehensive Dictionary of Psychological Terminology] Воронеж: НПО "Модек".

Bourguignon, E. 1976. Possession. San Francisco: Chandler and Sharp.

Camporesi, P. 1989. Bread of Dreams: Food and Fantasy in Early Modern Europe. Cambridge: Polity Press.

Chagin, G. N. 1998. Чагин, Г.Н. Окружающий мир в традищионном мировоззрении русских крестьян Среднего Урала [Тhe Surrounding World in the Traditional Worldview of the Russian Peasants of the Middle Urals]. Пермь: Пермский государственный университет. 
Crapanzano, V. (ed.). 1977. Case Studies in Spirit Possession. N.Y.: John Wiley and Sons.

Dal', V. N. 1882. Даль, В. Н. Толковый словарь живого великорусского языка [Comprehensive Dictionary of the Living Great Russian Language]. Ст. Петербург: Издание книгопродавца-типографа М.О. Вольфа.

Danforth, L. M. 1989. Firewalking and Religious Healing: The Anastenaria of Greece and the American Firewalking Movement. Princeton University Press. 3332

Drzhevetskii, A. I. 1872. Држевецкий А. И. Медико-топография Усть-Сысольского уезда Вологодской губернии [The Medical Topography of the Ust'-Sysol'sk District of the Vologda Region]. СПб: Печатня В.И. Головина.

Efimenko, P. S. 1864. Ефименко, П. С. “Демонология жителей Архангельской губернии" [Demonology of the Inhabitants of the Arkhangel'sk County] in Памятная книжка Архангельской губернии на 1864 год [Memorandum Book of Arkhangel'sk guberniia from 1864]. Архангельск: Издание Архангельского губернского статистического комитета, 49-93.

Efimenko, P. S. 1877. Ефименко, П. С. "Материалы по этнографии русского населения Архангельской губернии" [Ethnographic Data on the Russian Population of the Arkhangel'sk County], Известия императорского Общества любителей естествознания, антропологии и этнографии. [Proceedings of the Imperial Society of the Lovers of Natural History, Anthropology and Ethnography] T. 30. Вып. 1. Москва: Типография О.Б. Миллера.

Filin, F. P. 1977. Словарь русских народных говоров [Dictionary of Russian Folk Dialects], под ред. Ф. П. Филина и др. Ленинград: Академия Наук СССР. Вып. 12, 1977; Вып. 31, 1997.

Foster, G. M. 1965. "Peasant society and the image of limited good" American Anthropologist, 679(2): 293-315.

Golikova, S. V. 1995. Голикова, С. В. "Кликушество глазами священника" [Klikushestvo through the Eyes of a Priest], Религия и иерковь в Сибири 8: 103-111.

Goodman, F. D. 1996. "Las Multiples Caras de las Posesiones," Alteridades, 6(12): 101-116.

Harner, M. J. (ed.) 1973. Hallucinogens and Shamanism. N.Y.: Oxford University Press. 
Kleinman, A. K. 1980. Patients and Healers in the Context of Culture: An Exploration of the Border Land Between Anthropology, Medicine, and Psychiatry. Berkeley; London: University of California Press.

Klementovskii, A. 1860. Клементовский, А. Кликуши [The Klikushi]. Москва: Типография Каткова и Ко.

Konakov, N. D. (ed.) 1999. Конаков Н. Д. Мифология Коми. Энцииклопедия уральских мифологий. Т. 1. [Komi Mythology. Encyclopaedia of Ural Mythologies. Vol. 1]. Москва: ДИК, Сыктывкар.

Krainskii, N. V. 1900. Краинский, Н. В. Порча, кликуши и бесноватые как явления русской народной жизни [Hexing, Klikushi, and the Possessed as a Phenomenon of Russian Folk Life]. Новгород: Губернская типография.

Lavrov, A. S. 2000. Лавров, А. С. Колдовство и религия в России. 1700-1740 22 [Sorcery and Religion in Russia. 1700-1740]. Москва: Древлехранилище.

Lewis, I. M. 2003. Ecstatic Religion: A Study of Shamanism and Spirit Possession. 3rd ed. L. N.Y.: Routledge.

Limerov, P. F. 1998а. Лимеров, П. Ф. Коми несказочная проза [Komi Non-Folktale Prose]. Сыктывкар: Издательство Сыктывкарского государственного университета.

Limerov, P. F. 1998b. Лимеров, П. Ф. Мифология загробного мира [Mythology of the Other World]. Сыктывкар: Коми научный центр Уральского отделения Российской академии наук.

Littlewood, R. 2000. Cultural Psychiatry and Medical Anthropology: An Introduction and Reader. New Brunswick, N.J.: The Athlone Press.

Maksimov, S. V. 1987 [1859]. Максимов, С. В. "Год на Севере" [А Year in the North] in Избранные произведения [Selected Writings]. В 2-х тт. Москва: Художественная литература.

Mappen, M. (ed.) 1980. Witches and Historians: Interpretations of Salem. Malabar Fla.: Krieger Publications.

Martynov, S. V. 1905. Мартынов С. В. Печорский край. Очерки природы и быта, население, культура, промышленность [Тhe Pechora Region. Sketches on the Landscape, Everyday Life, Population, Culture, and Industry]. Ст. Петербург: Типография М. М. Стасюлевича.

Matossian, M. K. 1989. Poisons of the Past: Molds, Epidemics, and History. New Haven: Yale University Press. 
Mel'nikova, Е. А. 2006. Мельникова Е.А. “Отчитывание бесноватых: практики и дискурсы" [Exorsizing the Possessed: Customs and Discourses], Антропологический форум 4: 220-263.

Merkulova, V. А. 1988. Меркулова, В.А. "Три русских медицинских термина" [Three Russian Medical Terms] in Общеславянский лингвистический атлас. Материаль и исследования 1983. [PanSlavic Linguistic Atlas. Data and Research. 1983]. Москва: Наука.

Moroz, А. В. 1996. Мороз, А. Б. “А еще она страшно боялась пауков и лягушек" [And She Was Also Terribly Afraid of Spiders and Lizards], Живая Старина 1: 13-17.

Murdock, G. P. 1980. Theories of Illness: A World Survey. Pittsburgh: University of Pittsburgh Press.

Napol'skikh, V. V. 1999. Напольских, В. В. “Этимология коми шева" [Etymology of the Komi "sheva"], Linguistica Uralica 35(1): 4548.

Nikitina, S. Е. 1993. Никитина, С. Е. Устная народная культура и языковое сознание [Oral Folk Culture and Linguistic Consciousness]. Москва: Наука.

Nikitina, S. Е. 1996. Никитина, С. Е. "Икота” [Ikota], Живая Старина 1: 12 .

Novombergskii, N. Іа. 1906. Новомбергский, Н. Я. Колдовство в Московской Руси XVII столетия [Sorcery in Moscovite Rus' of the $17^{\text {th }}$ Century]. СПб.: Типография Альтшулера (Материалы по истории медицины в России. Т. III. Ч. 1)

Osipov, V. Р. 1905. Осипов, В. П. Одержимость гадами и ее место в классификации психозов [Possession by Serpents and Its Place in the Classification of Psychoses], Обозрение психиатрии, неврологии и медицинской психологии 2: 122-139.

Panchenko, А. А. 2002. Панченко, А. А. Христовщина и скопчество: фольклор и традиционная культура русских мистических сект [Khristovshchina and Skopchestvo: Folklore and Traditional Culture of Russian Mystical Sects]. Москва: ОГИ.

Pigin, A. V. 1998. Пигин, А. В. Из истории русской демонологии XVII века: Повесть о бесноватой жене Соломонии. Исследование и тексты [On the History of Russian Demonology in the $17^{\text {th }}$ Century: The Story of Solomoniia, a Possessed Woman. Research and Texts]. Ст. Петербург: Институт русской литературы (Пушкинский дом) Российской академии наук.

Popov, G. 1903. Попов, Г. Русская народно-бытовая медицина. По материалам этнографического бюро князя В. Н. Тенишева 
[Russian Folk Medicine. Data from the Ethnographic Division of Duke V. N. Tenishev]. Ст. Петербург: Типография А.C. Суворина.

Pozdeeva, I. V. 1997. Поздеева И. В. "Русское старообрядчество как объект комплексного гуманитарного исследования" [Russian Old Believers as an Object of a Complex Humanitarian Research] in Традиционная народная культура населения Урала. Материаль международной научно-практической конференции [Traditional Folk Culture of the Ural Population. Proceedings of the International Scientific-Applied Conference]. Пермь: Пермский областной краеведческий музей, 41-43.

Prince, R. H. (ed.) 1968. Trance and Possession States. Montreal: The R. M. Bucke Memorial Society.

Pryzhov, I. G. 1996 [1865]. Прыжов, И. Г. 26 московских пророков, юродивых, дур и дураков и другие труды по русской истории и этнографии [Twenty Six Moscovite Prophets, Holy Fools, FemaleFools, Male-Fools, and Other Works on Russian History and Ethnography]. Ст. Петербург: Эзро; Москва: Интрада.

Sharp, L. A. 1993. The Possessed and the Dispossessed: Spirits, Identity, and Power in a Madagascar Migrant Town. Berkeley: University of California Press.

Shteinberg 1870. Штейнберг, С.И. "Кликушество и его судебномедицинское значение" [Klikushestvo and Its Forensic Meaning], Архив судебной медицины и общественной гигиены 2: 64-81.

Sidorov, A. S. 1997[1928]. Сидоров, А. С. Знахарство, колдовство и порча у народа коми: Материаль по психологии колдовства [Healing, Sorcery, and Hexing among the Komi People: Data on the Psychology of Sorcery]. Ст. Петербург: Алетейя.

Simons R. C., Hughes C. C. 1985. The Culture-Bound Syndromes: Folk Illnesses of Psychiatric and Anthropological Interest. Dordrecht; Lancaster: Reidel.

Smilianskaia, Е. В. 1997. Смилянская Е. Б. "О некоторых особенностях крестьян-старообрядцев Верхокамья" (Certain Features of Old Believer Peasants in Verkhokam'e) in Традищионная народная культура населения Урала. Материальь международной научно-практической конференции. [Traditional Folk Culture of Ural Region. Proceedings of the International Scientific-Applied Conference]. Пермь: Пермский областной краеведческий музей, 119-124. 
Smilianskaia, E. В. 1998. Смилянская, Е. Б. "Микрокосм верхокамского старообрядца на исходе XX века" (The Microcosm of Verkhokam'e Old Believers at the turn of the $20^{\text {th }}$ century) in Старообрядческая культура Севера. [Old-Believer's Culture in Northern Regions]. Москва-Каргополь: Каргопольский историко-архитектурный и художественный музей-заповедник.

SUS - Сравнительный указатель сюжетов. Восточнославянская сказка [East Slavic tale type index] / Сост. Л. Г. Бараг и др. Л., 1979.

Vinogradova, L. N. 2000. Виноградова, Л. Н. Народная демонология и мифо-ритуальная традиция славян [Folk Demonology and Mythico-Ritual Tradition of the Slavs]. Москва: Индрик.

Ward, C. and M. Beaubrun. 1980. "The psychodynamics of demon possession," Journal for the scientific study of religion. 19: 201207.

Worobec, C. D. 2001. Possessed: Women, Witches and Demons in Imperial Russia. DeKalb: Northern Illinois University Press.

Translated by Svitlana Kukharenko 